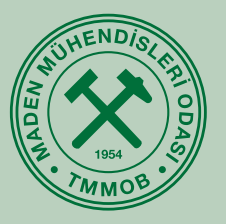

Orijinal Araştırma / Original Research

\title{
EXTRACTION OF NICKEL FROM A MIXED NICKEL-COBALT HYDROXIDE PRECIPITATE
}

\author{
KARIŞIK BIR NIKEL-KOBALT HIDROKSIT ÇÖKELEĞINDEN NIKEL KAZANIMI
}

Sait Kurşunoglua,

${ }^{a}$ Abdullah Gul University, Department of Materials Science \& Nanotechnology Engineering, Kayseri, TURKEY

\author{
Geliş Tarihi / Received : 11 April / Nisan 2018 \\ Kabul Tarihi / Accepted : 27 Eylül / September 2018
}

Anahtar Sözcükler:

Nickelextraction,

Mixed nickel-

cobalt hydroxide precipitate,

Sulphuricacid,

Amorphous solid structure.

\section{Öz}

The extraction of nickel from a mixed nickel-cobalt hydroxide precipitate (MHP) was conceived and experimentally explored. The effect of sulphuric acid concentration, leaching time, leaching temperature and stirring speed on nickel extraction was investigated. After 60 min leaching time, more than $90 \%$ of nickel and approximately $80 \%$ of cobalt were taken into the leach solution under the following conditions: $0.75 \mathrm{M}$ sulphuric acid concentration, $30^{\circ} \mathrm{C}$ leaching temperature and $400 \mathrm{rpm}$ stirring speed. $\mathrm{pH}$ of the leach slurry was determined as 1.23 under the conditions explored. It was observed that there is no beneficial effect of leaching temperature and stirring speed on the extraction of nickel from the MHP sample. The XRD pattern of the fresh MHP sample revealed the data and peak of the sample widening which is indicative of amorphous solid structure.

\section{ABSTRACT}

Keywords:

Nikel kazanımı,

Karışık nikel-kobalt hidroksit

çökeleği,

Sülfürikasit,

Amorfumsu katı yapı.
Karışık bir nikel-kobalt hidroksit çökeleğinden (MHP) nikel kazanımı tasarlanmış ve deneysel olarak araştırımıştır. Nikel kazanımı için sülfürik asit miktarının, liç süresinin, liç sıcaklığının ve karıştırma hızının etkileri incelenmiştir. $0,75 \mathrm{M}$ sülfürik asit miktarında, $30^{\circ} \mathrm{C}$ liç sıcaklığında ve 400 rpm karıştırma hızı şartlarında, 60 dakika liç işleminden sonra \%90'dan daha fazla nikel ve yaklaşık \%80 kobalt çözeltiye alınmıştır. Araştıılan koşullar altında katı-çözelti karışımının pH değeri 1,23 olarak belirlenmiştir. Liç sıcaklığının ve karıştırma hızının MHP numunesinden nikel kazanımına faydalı etkilerinin olmadığı gözlemlenmiştir. Yeni MHP numunesi üzerinde yapılan XRD incelemeleri sonrasında elde edilen sonuç ve piklerin oldukça geniş olması numunenin amorfumsu katı yapıda olduğunu ortaya çıkartmıştır. 


\section{INTRODUCTION}

Lateritic nickel ore is an important natural mineral resource that contains important amount of nickel and its primary by-product, cobalt. These metals are extensively used in modern metallurgical applications such as stainless steel, nickel coating, non-ferrous alloys, cobalt coating on copper surface, batteries and mobile phones. Due to the decrease in high-grade ore deposits and an increase in demand from metallurgical industry for strategic applications, researchers have concentrated on low-grade lateritic nickel ores.

In the last two decades, several new hydrometallurgical technologies have been proposed for nickel and cobalt extractions from laterite nickel ore such as sulphating atmospheric leaching (SAL), starved acid leaching technology (SALT), bioleaching of oxide ores, and Direct Nickel process (DNi) (Verbaan et al., 2007; Harris et al., 2004; McDonald and Whittington, 2008; Dreisinger and Clucas, 2013; Valix et al., 2001; Kyle, 2010; Brock and McCarthy, 2014). The main novelty of SAL process is that the concentrated sulfuric acid is added directly to lateritic nickel ore in a pug mill. Relatively low levels of sulfuric acid were used to dissolve nickel and cobalt from laterite ores using the SALT method, in conjunction with relatively low levels of iron dissolution. As an alternative to hydrometallurgical process, bio-hydrometallurgy has gained increasing attention because of the potential lower cost, lower energy demand, and safer operation compared to the conventional hydrometallurgical processes. In this process, the extraction of nickel and cobalt from lateritic nickel ore occurs with a range of fungal strains (i.e. Aspergillus niger, Penicilliumfuniculosum) that produce organic acids such as citric acid, oxalic acid, and acetic acid which enable the complexation of the metals (Tang and Valix, 2006). DNi process has been demonstrated at demonstration scale test plant (Brock and McCarthy, 2014). In this process, nitric acid is used instead of sulfuric acid to dissolve nickel within a few hours and the residual acid is then recycled. The main advantage of the process is that the process treats both limonite and saprolite ores and it is estimated to have less than half the capital and operating costs of HPAL or ferronickel processes.

There are three leaching methods currently applied for the hydrometallurgical extraction of nickel and cobalt from lateritic nickel ores, namely high pressure acid leaching (HPAL), atmospheric acid leaching $(A L)$ and heap leaching $(H L)$. Each process has its own advantages and disadvantages. The main advantages of HPAL are that the process requires much lower acid consumption, higher nickel and cobalt recoveries and faster dissolution kinetics than the other two methods. The main advantages of $A L$ are that it requires lower capital and energy costs than HPAL but able to provide comparable nickel and cobalt recoveries. Meanwhile, $\mathrm{HL}$ requires the least capital and energy costs among the three processes and produces clear leachate solution for downstream processing circumventing the need of a solid-liquid separation unit. This process, however, provides the least metals recoveries among the three, requires long leaching duration, inventory and cycle management (Kyle, 2010).

Recently, nickel and cobalt are dissolved by direct sulphuric acid leaching method from lateritic nickel ore in industrial scale. Nickel and cobalt are extracted from pregnant leach solution (PLS) by one of three methods. These methods are divided into three main categories depending on the downstream route: (i) mixed sulphide precipitation (MSP), (ii) mixed hydroxide precipitation (MHP) and (iii) direct solvent extraction (DSX) (Motteram et al., 1996; Manson et al., 1997; Mihaylov et al., 2000; Donegan, 2006).The MSP route has been in commercial operation for more than 55 years and is now the most used technique to recover the nickel and cobalt as a filter cake of mixed nickel and cobalt sulphides separating them from manganese, magnesium and calcium. It has been used at Moa Bay (Cuba), Murrin Murrin (Australia), Coral Bay (Philippines), Ambatovy (Madagascar) and Taganito (Philippines). The MHP route has been used at Cawse (Australia), Ravenstorphe (Australia) and Ramu 
(Papua New Guinea). This process is simpler to operate than the MSP process and is unsuitable for treating feed liquor with high manganese content. The DSX route is the newest addition among the three and has now been used in two commercial operations: Bulong (Australia) and Goro (New Caledonia). This process circumvents the need of intermediate precipitation of the nickel and cobalt and therefore, this approach offers a potential economic advantage over the two intermediate precipitation processes.

Nickel and cobalt are separated from each other and extracted from the resulting solutions by hydrogen reduction, electro-winning (EW) or precipitation. MSP route excludes more of the common impurities whereas MHP is increasingly popular because it omits the costly $\mathrm{H}_{2} \mathrm{~S}$ precipitation step and its product is easily soluble in ammonia or dilute sulphuric acid with a potential for the application of SX/EW (Taylor, 1995). It was noted that DSX had a high level of impurities like magnesium, calcium and iron (II) as well as considerable amount of gypsum formation and crud build-up formations in solvent extraction settlers (Donegan, 2006; Nofal et al., 2001; O'Callaghan, 2003). Due to high operating cost and technical risk of DSX, MHP route has been developed for refining with a simple and effective nickel and cobalt separation step (Mason and Hawker, 1998).

Hydrometallurgical route of nickel laterite ore is complex because of impurities such as aluminium, chromium, iron, calcium, magnesium and manganese. Cobalt, especially, is a value metal which is always present in lateritic nickel ores. After leaching of lateritic nickel ore, aluminium, chromium and iron are precipitated by $\mathrm{CaCO}_{3}$, $\mathrm{CaO}$ or $\mathrm{MgO}$, leaving nickel, cobalt, manganese, calcium and magnesium in solution. Further, sulphide or hydroxide precipitation is conducted to achieve manganese, calcium, magnesium separation from nickel and cobalt. Hydroxide precipitation; however, is less selective towards manganese (Harvey et al., 2011).
High pressure acid leaching (HPAL) technique is currently used by Meta Nickel, Gordes/Turkey to extract nickel and cobalt from lateritic nickel ore. PLS is fed to first partial neutralisation unit to remove impurities such as iron, aluminium, chromium by increasing $\mathrm{pH}$ of the leach solution up to $~ 3.3$. The neutralised leach solution is send to second neutralisation unit to achieve complete rejection of the impurities by increasing $\mathrm{pH}$ of the leach solution from $\sim 3.3$ to $\sim 5.5$ and then the leach solution is precipitated by using $\mathrm{MgO}$ to obtain MHP product. The MHP product depending on PLS consists of $\sim 34-38 \% \mathrm{Ni}$ and $\sim 1$. 8 $2.1 \%$ Co along with other impurities such as manganese, magnesium and calcium. In the present study, the main objective was to investigate the extraction of nickel from the MHP product using direct sulphuric acid leaching under atmospheric conditions to understand the effect of sulphuric acid concentration, leaching temperature, stirring speed and leaching time.

\section{MATERIALS AND METHOD}

\subsection{MHP Sample}

The fresh MHP sample was kindly provided by Meta Nickel Plant in Gordes/Turkey. The supplied sample was crushed with a jaw crusher and reduced to less than $425 \mu \mathrm{m}$ using a laboratory ball mill. The fresh MHP sample was given in Figure 1. The particle size distribution of the sample was measured using Master Sizer 2000 (Malvern). The elemental composition of the sample was analysed using X-ray fluorescence (XRF) spectrometer (Zetium, PANalytical), while its mineralogical composition was examined using X-ray diffraction (XRD) (Empyrean, PANalytical) with $\mathrm{CuK}_{\alpha 1}$ (wavelength $1.5406 \AA$ ) operating at 45 $\mathrm{kV}$ and $40 \mathrm{~mA}$. The XRD $2 \theta$ diffraction angle was calibrated using $2 \theta / \mathrm{d}$-spacing calibration standard. Subsequently, minerals were identified using the ICCD PDF-4 Plus/Minerals software. The wt. $\%$ of nickel was determined on a Thermo Scientific 3300 atomic absorption spectrophotometer (AAS) after digestion of the fresh MHP sample in hot aqua regia (3:1, $\mathrm{HCl}: \mathrm{HNO} 3)$. 


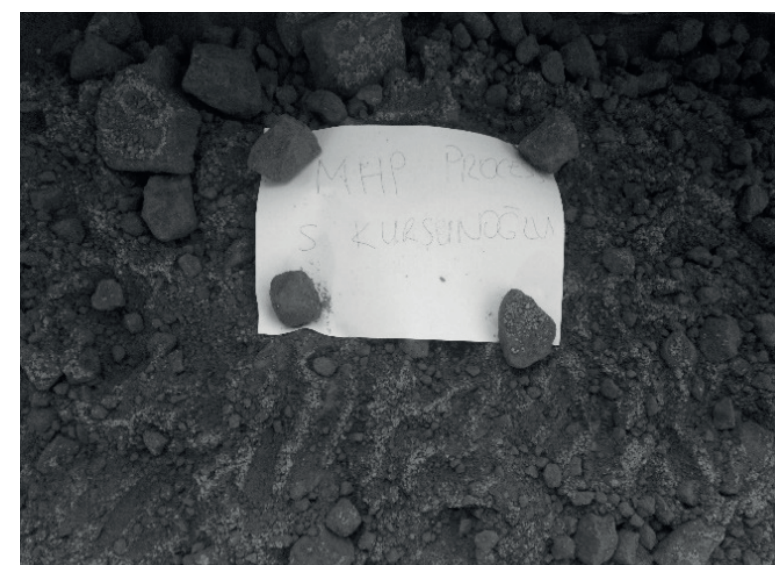

Figure 1. Fresh MHP sample

\subsection{Experimental Procedure}

The leaching tests were performed in an approximately $600 \mathrm{~cm}^{3}$ glass reactor covered with aluminium foil to prevent evaporation. The leach slurry was mixed by an overhead mechanical stirrer (MTOPS-MS3040D) with a three-blade stainless steel impeller (45 mm diameter) at 400 rpm. The reactor and slurry were maintained at the required temperature by a hotplate heater. For each experiment, $50 \mathrm{~g}$ ore were transferred into the reactor before adding $500 \mathrm{~cm}^{3}$ of sulphuric acid at a pre-determined concentration and then heated to the desired temperature. At selected time intervals, a fix amount of slurry (10 $\mathrm{cm}^{3}$ ) was withdrawn, and the $\mathrm{pH}$ of the slurry was measured by $\mathrm{pH}$ meter (Hach, HQ40d) equipped with IntelliCAL PHC 28101 probe, and lastly the slurry was centrifuged at $7500 \mathrm{rpm}$. Supernatant liquor was diluted and analysed by AAS. In the leaching tests, analytical grade of sulphuric acid (95-97\% purity, Merck) was used in acid preparation. In all leaching tests, solid-to-liquid ratio was maintained at $1 / 10(w / v)$. The leaching tests were duplicated to assess the reproducibility of the test results. Extraction of nickel was calculated according to the following equation:

Extraction $(\%)=$

$\left[\frac{\text { Metal in the leach liquor by AAS, } \%}{\text { Metal in the fresh MHP sample by AAS, } \%} \times 100\right]$

\section{RESULTS AND DISCUSSION}

\subsection{Materials Characterization}

The particle size distribution of the sample is shown in Figure 2. The results showed that $90 \%$ of the sample is less than $43.1 \mu \mathrm{m}$. The elemental composition of the sample was given in Table 1. The elemental concentrations of nickel and cobalt were determined as 34.5 and $1.9 \%$, respectively by AAS. Figure 3 shows a XRD pattern of the MHP sample.

Table 1. Elemental composition of the MHP by XRF

\begin{tabular}{cc}
\hline Elements (MHP) & wt.\% \\
\hline $\mathrm{Mn}$ & 5.63 \\
$\mathrm{Fe}$ & 0.56 \\
$\mathrm{Cr}$ & 0.04 \\
$\mathrm{Sc}$ & 0.02 \\
$\mathrm{Zn}$ & 0.45 \\
$\mathrm{Cu}$ & 0.22 \\
$\mathrm{Co}$ & 2.1 \\
$\mathrm{Ni}$ & 37.7 \\
$\mathrm{Mg}$ & 2.42 \\
$\mathrm{Al}$ & 0.9 \\
\hline
\end{tabular}

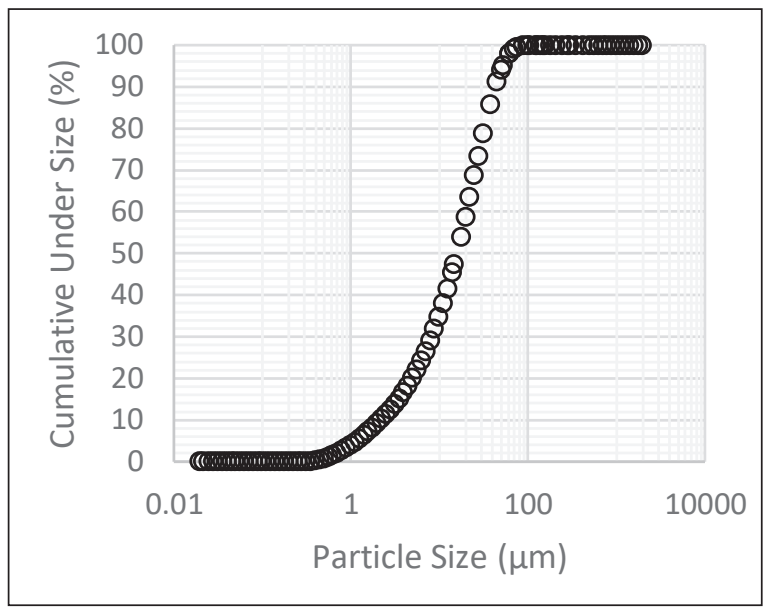

Figure 2. Particle size distribution of the MHP sample

The XRD results revealed the data and peak of the sample widening which is indicative of amorphous solid structure. It is known that determination of amorphous structure of solid sample is difficult. The characteristic peaks of $\alpha-\mathrm{Ni}(\mathrm{OH})_{2} \cdot 0.75 \mathrm{H}_{2} \mathrm{O}$ 
(card No: 00-038-0715-Jamborite) nickel hydroxide obtained from sulphate solution achieved at 2-Theta $=34$ and 59. The peaks at 2-Theta $=12$ and 23 were also determined as characteristics of $\mathrm{a}-\mathrm{Ni}(\mathrm{OH})_{2} \cdot 0.75 \mathrm{H}_{2} \mathrm{O}$, which is consistent with findings of Rajamathi et al., 1997, Harvey et al., 2011.

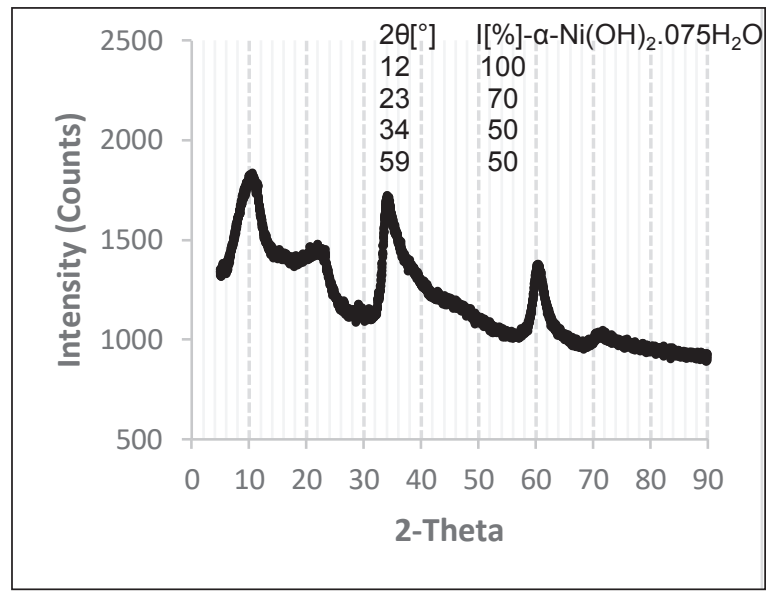

Figure 3. XRD pattern of the MHP sample

\subsection{Effect of Sulphuric Acid Concentration on Extraction}

A series of leaching tests was carried out at various sulphuric acid concentrations $(0.5,0.75$ and 1.0M). The leaching time, temperature, stirring speed and solid-to-liquid ratio were fixed at $3 \mathrm{~h}$, $70^{\circ} \mathrm{C}, 400 \mathrm{rpm}$ and $1 / 10$, respectively. Equation 2 shows the precipitation of metals from aqueous solution as hydroxides. $M$ is the metal cation and $\mathrm{n}$ is the cation charge. According to Equation 3, nickel hydroxide precipitate can dissolve in aqueous sulphuric acid solution.

$\mathrm{M}^{\mathrm{n}+}+\mathrm{nH}_{2} \mathrm{O}=\mathrm{M}(\mathrm{OH}) \mathrm{n}+\mathrm{nH}^{+}$

$\mathrm{Ni}(\mathrm{OH})_{2}(\mathrm{~s})+\mathrm{H}_{2} \mathrm{SO}_{4}(\mathrm{aq}) \rightarrow \mathrm{NiSO}_{4}(\mathrm{aq})+\mathrm{H}_{2} \mathrm{O}(\mathrm{I})(3)$

Figure 4 shows the effect of sulphuric acid concentration on the nickel extraction from the MHP sample at $70^{\circ} \mathrm{C}$. The extraction rate of the nickel significantly increased with increasing concentration of sulphuric acid. The extraction of nickel increased from $83.2 \%$ to $96.2 \%$ when the acid concentration increased from $0.5 \mathrm{M}$ to $0.75 \mathrm{M}$ at
$70{ }^{\circ} \mathrm{C}$ for $3 \mathrm{~h}$ and then relatively maintained constant. It may be due to acid consuming alkaline phases such as magnesium and calcium hydroxide in the product. Figure 5 shows the slurry $\mathrm{pH}$ changes. The $\mathrm{pH}$ of the slurry decreased from 4.9 to 1.0 when the acid concentration increased. Thus, nickel extraction rate increased depending on ionic activity of the solution.

\subsection{Effect of Leaching Time on Extraction}

Leaching experiments was conducted with sulphuric acid concentration of $0.75 \mathrm{M}$ and temperature of $70^{\circ} \mathrm{C}$ as a function of time with a $1 / 10(\mathrm{w} / \mathrm{v})$ solid-to-liquid ratio and a stirring speed of 400 rpm. Figure 6 shows the effect of leaching time on the nickel extraction from the MHP sample. The extraction of nickel increased with increasing leaching time up to $60 \mathrm{~min}$ and then slightly increased until $180 \mathrm{~min}$. As can be seen from Figure 6 , the extraction of nickel is achieved within $60 \mathrm{~min}$. Therefore, the leaching time should be selected as $60 \mathrm{~min}$ for the extraction of nickel from the MHP sample. Figure 7 shows the slurry $\mathrm{pH}$ changes during the leaching process. The $\mathrm{pH}$ of the slurry slightly increased within the first $30 \mathrm{~min}$ and then stayed relatively constant. This means that the ionic activity of the solution remained constant when the leaching time extended from $60 \mathrm{~min}$ to $180 \mathrm{~min}$.

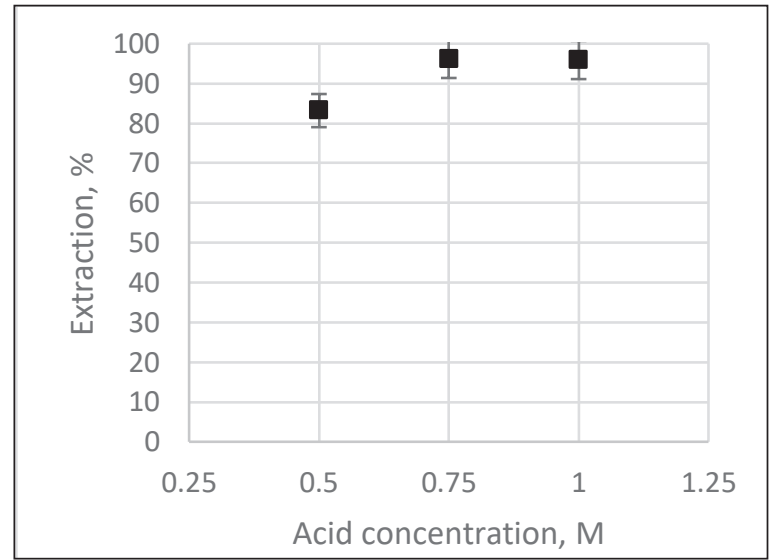

Figure 4. Effect of sulphuric acid concentration on extraction (Conditions: Temperature of $70^{\circ} \mathrm{C}$,leaching time of $180 \mathrm{~min}$, solid-to-liquid ratio of $1 / 10$, stirring speed $400 \mathrm{rpm}$ ) 


\subsection{Effect of Stirring Speed on Extraction}

The effect of the stirring speed on the nickel extraction was evaluated at $500-600 \mathrm{rpm}$ and $70^{\circ} \mathrm{C}$ with $0.75 \mathrm{M}$ sulphuric acid as a function of leaching time (Figure 8 ). The solid-to-liquid ratio was held constant at 1/10 (w/v). Nickel extraction slightly increased with increasing leaching time. As can understand from the Figure 8, there was no beneficial effect of stirring speed on the extraction of nickel. Therefore, the stirring speed can be held at $400 \mathrm{rpm}$ to achieve homogenous mixing of the leach slurry.

\subsection{Effect of Temperature on Extraction}

The leaching curves of nickel and cobalt at different temperatures are shown in Figure 9. The following conditions were performed in the effect of temperature studies: a 1/10 (w/v) solid-to-liquid ratio, $0.75 \mathrm{M}$ sulphuric acid, $180 \mathrm{~min}$ leaching time and a constant stirring speed of $400 \mathrm{rpm}$. The extraction of nickel slightly increased with increasing leaching temperature whereas the extraction of cobalt remained relatively constant. As can be seen from the Figure 9, there is no benefit gained in the leaching of nickel and cobalt by increasing leaching temperature. Therefore, the extraction of nickel can be achieved at $30^{\circ} \mathrm{C}$. These results are in agreement with the finding of Harvey et al., 2011.

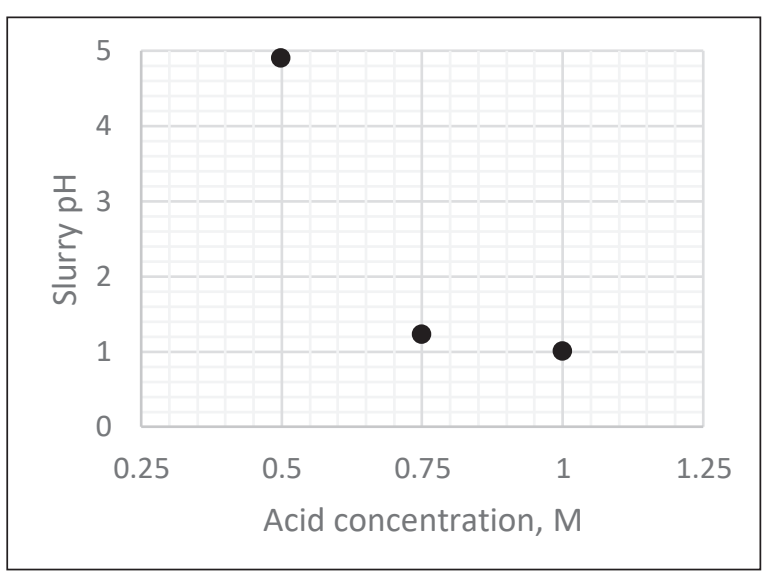

Figure 5. $\mathrm{pH}$ changes of the leach slurry

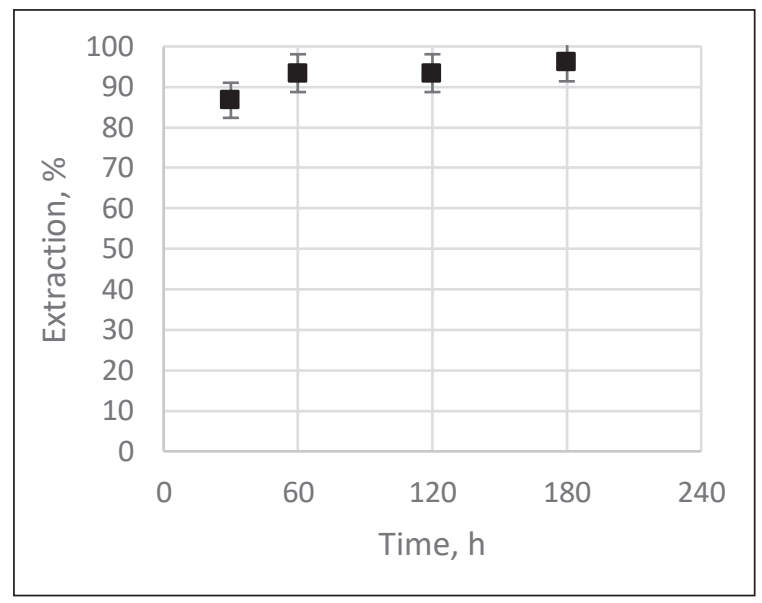

Figure 6. Effect of leaching time on extraction (Conditions: Sulphuric acid concentration of $0.75 \mathrm{M}$, temperature of $70^{\circ} \mathrm{C}$, solid-to-liquid ratio of $1 / 10$, stirring speed of $400 \mathrm{rpm}$ )

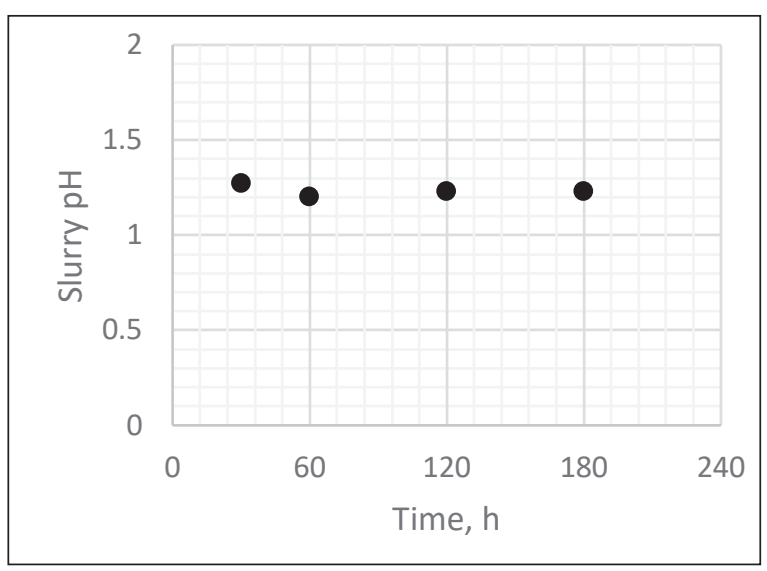

Figure 7.pH changes of the leach slurry

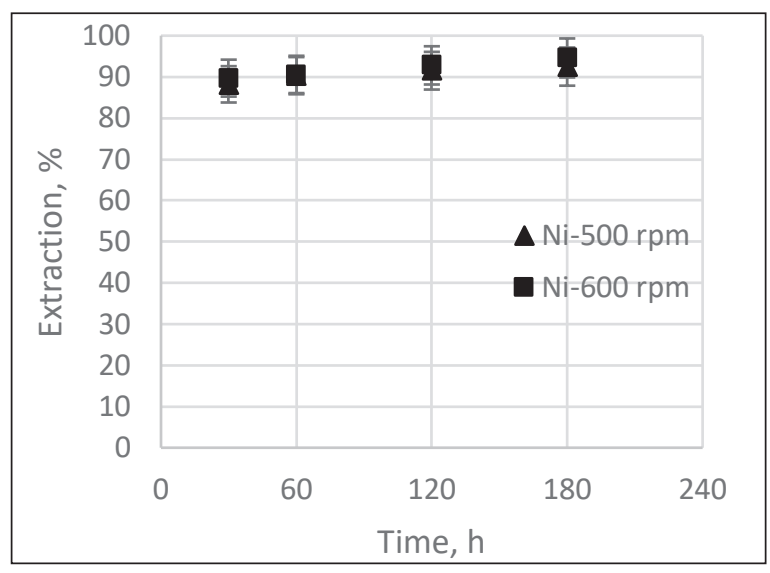

Figure 8.Effect of stirring speed on extraction (Conditions: Sulphuric acid concentration of $0.75 \mathrm{M}$, temperature of $70^{\circ} \mathrm{C}$, solid-to-liquid ratio of $1 / 10$ ) 


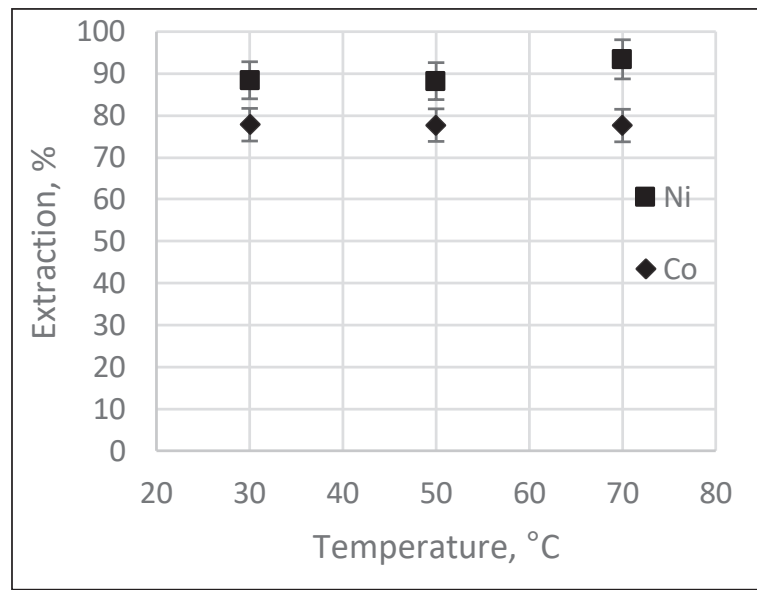

Figure 9. Effect of temperature on extraction (Conditions: Sulphuric acid concentration of $0.75 \mathrm{M}$, leaching time of $180 \mathrm{~min}$, solid-to-liquid ratio of $1 / 10$, stirring speed $400 \mathrm{rpm}$ )

\section{CONCLUSIONS}

Nickel was extracted from a mixed nickel-cobalt hydroxide precipitate with excellent extraction under atmospheric pressure acidic leaching conditions. The effects of four experimental variables were evaluated. After leaching experiments, the maximum nickel extraction in this study was achieved under the following conditions: $0.75 \mathrm{M}$ sulphuric acid, $30^{\circ} \mathrm{C}$, a $1 / 10$ solid-to-liquid ratio $(w / v)$, a leaching time of $60 \mathrm{~min}$, and a stirring speed of $400 \mathrm{rpm}$. Under these conditions, more than $90 \%$ of the nickel and approximately $80 \%$ of cobalt were taken into the leach solution. The extraction of nickel slightly increased after $30 \mathrm{~min}$ leaching time and then remained constant while the extraction of cobalt was relatively stable. It was found that there is no influential effect of leaching temperature and stirring speed on the extraction of nickel. Effective nickel extraction could be achieved using $30^{\circ} \mathrm{C}$ leaching temperature from the mixed nickel-cobalt hydroxide product under the conditions explored. The XRD result of the MHP sample demonstrated that sample has an amorphous solid structure.

\section{ACKNOWLEDGEMENTS}

Author thanks Dr. H. S. Gokcen and Dr. Y. H. Gursoy from Eskisehir Osmangazi University, Department of Mining Engineering for PSA, XRF and XRD analyses, and Meta Nickel for supplying the MHP sample. Author is also grateful to A. F. Yazici from Abdullah Gul University for proofreading of the manuscript.

\section{REFERENCES}

Brock, G., Mccarthy, F., 2014. Direct Nickel Test Plant Progr: 2013 in review. In: ALTA Nickel-Cobalt-Copper Conference, Perth, Western Australia.

Donegan, S., 2006. Direct Solvent Extraction of Nickel at Bulong operations. Miner. Eng., 19, 1234-1245.

Dreisinger, D., Clucas, J. In: Battle, T., et al. (Eds.), 2013. The Starved Acid Leaching Technology (Salt) for Recovery of Nickel and Cobalt from Saprolites and Caron Plant Residues. John Wiley \& Sons, Inc., Hoboken, NJ, USA.

Harris, G.B., Magee, T.J., Lakshmanan, V.I., Sridhar, R. 2004. The Jaguar Nickel Inc. Sechol Laterite Project Atmospheric Chloride Leach Process. In: Imrie, W.P., et al. (Eds.), International Laterite Nickel Symposium. TMS, Warrendale, 219-241.

Harvey, R., Hannah, R., Vaughan, J., 2011. Selective Precipitation of Mixed Nickel-Cobalt Hydroxide. Hydrometallurgy, 105, 222-228.

Kyle, J., 2010. Nickel Laterite Processing Technologies-Where to Next? Alta Nickel/Cobalt/ Copper Conference, 24-27 May, Perth, Western Australia.

Manson, P.G., Groutsch, J.V., Mayze, R.S., White, D., 1997. Process Development \& Plant Design for the Cawse Nickel Project. Alta Nickel/Cobalt Forum, 1-14.

Mason, P., Hawker, M., 1998. Ramu Nickel Process Piloting. Proceeding of ALTA Nickel Cobalt Pressure Leaching and Hydrometallurgy Forum. ALTA Metallurgical Services, 1-38.

Mcdonald, R.G., Whittington, B.I., 2008 Atmospheric Acid Leaching of Nickel Laterites Review Part I. Sulphuric Acid Technologies. Hydrometallurgy, 91, 35-55.

Mihaylov, I., Krause, E., Colton, D.F., Okita, Y., Duterque, J.P., Perraud, J.J., 2000. The Development of a Novel Hydrometallurgical Process for Nickel and Cobalt Recovery from Goro Laterite Ore. Metall. Soc. CIM, 93, 124-130. 
Motteram, G., Ryan, M., Berezowsky, R., Raudsepp, R., 1996. Murrin Nickel/Cobalt Project Development Overview. Alta Nickel/Cobalt Forum, 1-17.

Nofal, P., Allen, S., Hosking, P., Showell, T., 2001. Gypsum Control at Bulong: the final hurdle?. Proceedings of ALTA Nickel Cobalt Conference. ALTA Metallurgical Services, 1-15.

O'Callghan, J., 2003. Process Improvements at Bulong Operations. Pty Ltd. Alta Nickel/Cobalt Forum, 1-23.

Rajamathi, M., Gonur, N., Subbannab, N., Kamatha, P. V., 1997. J. Mater. Chem., 7, 2293-2296.

Tang, J.A., Valix, M., 2006. Leaching of Low Grade Li- monite and Nontronite Ores by Fungi Metabolic Acids. Miner. Eng., 19, 1274-1279.

Taylor, A., 1995. Laterites-Has the Time Finally Come? Min. Mag., 172 (3), 167-170.

Valix, M., Usai, F., Malik, R., 2001. Fungal Bio-Leaching of Low Grade Laterite Ores. Miner. Eng., 14 (2), 197-203.

Verbaan, N., Sist, F., Mackie, S., Todd, I., 2007. Development and Plotting of Skye Resources' Atmospheric Leach (SAL) Process at SGS Minerals. Alta Nickel/ Cobalt Conference, Perth. Alta Metallurgical Services, Melbourne. 